\section{1. 聴神経腫瘍の自然歴と治療選択}

\section{神戸大学脳神経外科}

甲村 英二

脳幹圧迫を伴う巨大な聴神経腫瘍に対して早期の手術治療 が必要であるという方針に異論はないと考えられる，小腫瘍 に対しての治療は, 経過観察, 定位的放射線治療, 手術治療 の選択肢があり，自然歴と治療法の長所短所を総合して方針 を決定する必要がある．数年間という比較的短期についてで はあるが小腫瘍の自然歴が諸家により明らかにされつつあ る.急速な増大例もあるが, 腫瘍の成長は約 $1 \sim 2 \mathrm{~mm} /$ 年と 報告されている.さらに, 約 30〜70\%では大きさに変化なく, 逆に縮小を示す例も5〜20\%程度で存在するとされている. 聴機能については腫瘍増大に関係なく悪化を示していくとす る報告が多い. 腫瘍制御の側面からは手術治療が, 聴機能温 存 ・低侵襲性の側面からは定位的放射線治療に利点があると 一般に考えられている. 自然歴に関しては, 地域差, 施設差 は恐らく存在しないと推測されるが，治療成績は施設により 明らかに異なるはずである. 各治療施設での成績, 患者の年 齢を考慮して, 患者説明, 治療方針の決定にあたる必要があ る.

\section{2. 頭蓋咽頭腫の自然歴と治療}

名古屋大学脳神経外科

齋藤 清, 永谷 哲也, 吉田純

頭蓋咽頭腫には一般に摘出手術と定位放射線治療が選択さ れている，手術による全摘出が理想であるが，視床下部下垂 体機能温存は困難である。どこまで安全に摘出できるのか, 術中の判断は容易ではない. 定位放射線療法についても, 視 神経に対する危険性や治療後の再発などもあり，手術と定位 放射線療法の組み合わせで機能予後の改善が得られるかにつ いても疑問が残る。術後急性期には高度の視床下部下垂体機 能低下がみられ，この管理が治療成績向上には必要である。

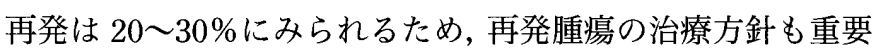
となる.我々は過去 16 年間に 61 例の手術を行った.これら の経験および文献上のエビデンスから, 自然歴, 治療法の選 択, 手術方法, 術後管理, 再発に対する治療, 長期予後につ いて検討し, 現段階で必要とされる標準治療法と到達すべき 成績などについて考察する.

\section{3. 頭蓋底髄膜腫の治療オプションと pitfall一頭蓋 底手術, 放射線手術の利点と欠点 \\ 金沢大学脳神経外科 \\ 長谷川光広, 山下 純宏}

一般的に髄膜腫は, 組織学的悪性度よりむしろ腫瘍の局在 とそれに関連した摘出度 resectability が患者の予後に大きく 影響する. 頭蓋底髄膜腫は, 前, 中, 後頭蓋窩ともに脳神経, 主要血管を巻き込み, 複数のアプローチによってもその摘出 に難渋することが少なくない，術後の複視，顔面神経麻痺， 聴力障害, 下位脳神経麻痺の出現は長期にわたり患者の $\mathrm{ADL}$ を損なうので, 腫瘍が線維性で硬く脳組織との瘉着が存 在する場合には術後の機能予後を考慮して亜全摘にとどめ, 後療法として放射線手術を追加する方法が現在一般的であ る。これにより, 術直後の治療成績は向上しているが, この 方針における長期予後に関する結論は得られていない.した がって，自然経過，手術治療及び残存させた場合の再増大， 放射線治療（単独あるいは手術との併用）のそれぞれの長期 予後を症例ごとに想定し，最善の治療法を選択しなければな らない，本発表では，自験例のなかから，頭蓋底髄膜腫の代 表例を提示し, 頭蓋底手術, 放射線手術の利点とピットフォー ルについて考察する.

\section{4. 良性脸腫瘍の自然歴および定位放射線療法の意 義}

中村記念病院脳神経外科
福岡 誠一 中村 博彦

良性脳腫瘍のうち, 脳神経機能温存の面から聴神経腫瘍, 頭蓋底髄膜腫などをガンマナイフにより治療し 13 年を経 た。この治療成績より過去のコングレスにて特に聴神経腫瘍 の制御率，機能温存率，適応について言及してきたが，今回 はこの腫瘍の治療後に起き得る一過性膨大（稀に 2 相性）, 稀な慢性の腫瘍内出血などの pitfall, 再発時の治療方針つき 検討を加える。一方，頭蓋底髄膜腫，頭蓋咽頭腫，海綿静脈 洞に進展した下垂体腫瘍に関しては大きさとともに視神経系 との位置関係が重要であり，線量計画上の制約が制御率に与 える影響について個々の腫瘍につき分析し，これらの腫瘍に 対するガンマナイフの適応，さらに開頭摘出術との相補関係 につき考察する。 